Ireneusz Bobrowski

Instytut Języka Polskiego PAN, Uniwersytet Jagielloński, Kraków

ireneusz.bobrowski@uj.edu.pl

\title{
ROMANA LASKOWSKIEGO KONCEPCJA OPISU KATEGORII RODZAJU W JĘZYKU POLSKIM
}

Słowa klucze: gramatyka polska, składnia, morfologia, rodzaj gramatyczny Keywords: Polish grammar, syntax, morphology, grammatical gender

W połowie lat 70. poprzedniego wieku najczęściej dyskutowaną kwestią w polonistycznym środowisku językoznawczym była koncepcja teoretyczna uniwersyteckiej Gramatyki współczesnego języka polskiego. Dwutomowe dzieło, które się ukazało drukiem w roku 1984 pod redakcją Stanisława Urbańczyka (GWJP 1984), zostało ostatecznie napisane i zredagowane przez dość wąską grupę autorów. Trzeba jednak mieć na uwadze to, iż w wypracowywaniu jego podstaw teoretycznych uczestniczyło wielu innych badaczy reprezentujących różne ośrodki językoznawcze i wyznających odmienne poglądy metodologiczne. W artykule tym przedstawiam i komentuję jedno tylko rozwiązanie przyjęte w GWJP. Było ono jednak bardzo ważne dla całego dzieła, a przede wszystkim dla pierwszej części tomu morfologicznego. Chodzi mi mianowicie o koncepcję ujęcia kategorii rodzaju gramatycznego, którą zaproponował Roman Laskowski (por. Laskowski 1998).

Sam opis tej koncepcji, który znajduje się w tekście GWJP (zarówno w pierwszym, jak i w drugim jej wydaniu), jest bardzo precyzyjny, ale jednocześnie niezwykle skrótowy. Zapewne z powodu właśnie owej skrótowości opisu nie zyskała ona u nas takiej recepcji, na jaką bez wątpienia zasłużyła. $Z$ rozmów $z$ wieloma językoznawcami odniosłem wrażenie, że problem opisu rodzaju gramatycznego jest dla nich w dalszym ciągu bardzo zagadkowy. W artykule tym staram się więc nie tylko zrekonstruować 
kontekst, w jakim powstała teoria rodzaju gramatycznego Romana Laskowskiego, ale też $\mathrm{w}$ prosty sposób ją zreferować. Wskażę również na niektóre kwestie sporne, a na zakończenie przedstawię zarys koncepcji swojego autorstwa. Zrodziła się ona w czasie dyskusji z twórcą teorii rodzaju będącej przedmiotem tego szkicu.

Do roku 1956, tj. do opublikowania przełomowego artykułu Witolda Mańczaka (Mańczak 1956), w gramatykach polskich mówiono o trzech rodzajach rzeczownika: męskim, żeńskim i nijakim. Zauważono też - oczywiście - iż czasownik tworzący z rzeczownikiem podmiotowym związek główny w czasie przeszłym, przyszłym złożonym $\mathrm{z}$ formą kończącą się na - - - i w trybie przypuszczającym przyjmuje w liczbie mnogiej tylko dwa rodzaje. Inaczej zachowuje się w sąsiedztwie rzeczownika rodzaju męskiego nazywającego osobę, a inaczej w sąsiedztwie pozostałych rzeczowników. Fakt ten jednak nie wpływał na ujęcia rodzaju gramatycznego rzeczowników. Wprawdzie z tekstu Gramatyki języka polskiego Stanisława Szobera (Szober 1953) odczytać można pogląd, że jej autor jest zwolennikiem koncepcji, zgodnie z którą rzeczownikowi w liczbie pojedynczej przypisywany jest jeden $\mathrm{z}$ trzech rodzajów (albo męski, albo żeński, albo nijaki), a liczbie mnogiej jeden z dwóch (albo męskoosobowy, albo niemęskoosobowy), w sposób eksplicytny zasada ta nie została jednak tam sformułowana. Za koncepcją tą opowiada się w najnowszej dyskusji o rodzaju Andrzej Bogusławski (2009), zwracając jednocześnie uwagę, że pierwszym jej zwolennikiem był Witold Doroszewski.

$\mathrm{W}$ rozprawce przywołanej w poprzednim akapicie Witold Mańczak dowodzi, że każdy rzeczownik polski posiada nie jeden $\mathrm{z}$ trzech, ale jeden z pięciu rodzajów gramatycznych i że wynika to nie tyle z obserwacji związku głównego zdania, ile z obserwacji związku zgody pomiędzy rzeczownikiem a przymiotnikiem. Rzeczowniki pan i pies $\mathrm{w}$ bierniku liczby pojedynczej tworzą z przymiotnikiem inną grupę niż rzeczownik dom (widzę dobrego pana, psa, ale widzę dobry dom). Wyraźnie zatem należy oddzielić rzeczowniki w rodzaju męskożywotnym od rzeczowników w rodzaju męskonieżywotnym. Jeżeli jednak pod uwagę weźmiemy połączenia rzeczowników w bierniku liczby mnogiej, to się okaże, że rzeczownik pan tworzy z przymiotnikiem inną grupę niż rzeczowniki pies i dom (widzę dobrych panów, ale widzę dobre psy, domy). Trzeba więc oddzielić rzeczowniki w rodzaju męskoosobowym od rzeczowników w rodzaju męskożywotnym i męskonieżywotnym. Każdemu rzeczownikowi polskiemu przypisać zatem należy nie jeden z trzech, ale jeden z pięciu rodzajów: albo męskoosobowy (pan), albo męskożywotny (pies), albo męskonieżywotny (dom), albo żeński (pani), albo nijaki (okno). Zauważmy przy tym, że takie ujęcie sprawia, iż jesteśmy w stanie poprawnie opisać relacje rodzajowe zachodzące w związku głównym rzeczowniki rodzaju męskoosobowego nakazują wybór w liczbie mnogiej czasownika formy rodzaju męskoosobowego (panowie byli), natomiast rzeczowniki w pozostałych rodzajach wymagają formy niemęskoosobowej ( $p s y$, domy, panie, okna były).

Ujęcie Witolda Mańczaka zostało przez Romana Laskowskiego uznane za podstawę koncepcji kategorii rodzaju gramatycznego w GWJP. Tym samym opowiedział 
się on po stronie Mariana Kucały (por. Kucała 1978), który w dyskusji z Zygmuntem Salonim zakwestionował potrzebę odwoływania się do innych kontekstów (przede wszystkim liczebnikowych). Połączenia rzeczowników z liczebnikami stanowią dla Z. Saloniego (por. Saloni 1976) podstawę do wyodrębnienia kolejnych rodzajów rzeczowników: rodzaju nijakiego pierwszego ( wa okna), rodzaju nijakiego drugiego (dwoje dzieci), a także osobnego rodzaju dla rzeczowników pluralnych typu drzwi (dwoje drzwi). Zdaniem R. Laskowskiego klasy wyodrębnione przez Z. Saloniego na podstawie łączliwości rzeczowników z liczebnikami mają charakter drugoplanowy i są hierarchicznie podporządkowane podziałowi na pięć klas rodzajowych zaproponowanych przez W. Mańczaka.

Nie znaczy to jednak, że R. Laskowski nie wprowadza żadnych poprawek do koncepcji W. Mańczaka. Uznaje on bowiem, że potrzebny jest jeszcze jeden rodzaj dla rzeczowników typu cham czy łobuz. Zauważmy, że konteksty, w których pojawia się rzeczownik cham w liczbie mnogiej, nie pozwalają przyjąć, że jest on rodzaju męskoosobowego, bo możliwe jest tylko połączenie te chamy przyszły, a niemożliwe ${ }^{*}$ ci chami przyszli. Nie można wszakże uznać, że jest to rzeczownik rodzaju męskożywotnego, bo w bierniku liczby mnogiej nie zachowuje się on jak rzeczownik kot (niemożliwe jest połączenie * widzę te chamy), ale dokładnie tak jak rzeczownik pan (widzę tych chamów). Z tego powodu wprowadza autor osobny rodzaj męskoosobowy pejoratywny dla stosunkowo małej klasy rzeczowników typu cham. W istocie jednak - jak zauważa sam R. Laskowski - wszystkie leksemy męskoosobowe (pan, dyrektor, inżynier) mogą wystąpić w tych kontekstach, w których występują leksemy typu cham (te pany, inżyniery, dyrektory przyszły).

$\mathrm{W}$ osobnym artykule proponuję (por. Bobrowski 2006b), by połączenia typu $d y$ rektory przyszły traktować jako rezultaty operacji, którą nazwałem pejoratywizacją. Jej nieformalną eksplikację można by sformułować w następujący sposób:

Zastąp formę rzeczownika liczby mnogiej rodzaju męskoosobowego formą rzeczownika liczby mnogiej rodzaju niemęskoosobowego, zmieniając jednocześnie jej rząd rodzajowy.

Operacja taka zachodzi między innymi w zdaniu te nowoczesne inżyniery przyszły, a nie zachodzi w zdaniu ci nowocześni inżynierowie przyszli. Ma ona zatem charakter operacji fakultatywnej. Ale nie zawsze. W wypadku leksemów typu cham, łobuz operacja ta ma charakter obowiązkowy. Można zatem założyć, że zarówno rzeczowniki typu pan, inżynier, jak i cham, łobuz są rzeczownikami rodzaju męskoosobowego, różnią się tylko tym, że w mianowniku liczby mnogiej do pierwszych pejoratywizacja jest stosowana fakultatywnie, do drugich obligatoryjnie. Zauważmy przy tym, że w opisie pejoratywizacji ograniczyliśmy ją do mianownika liczby mnogiej. Biernika liczby mnogiej ona nie obejmuje. Wydaje się zatem, że powiększanie zaproponowanej przez W. Mańczaka liczby klas rodzajowych rzeczowników nie jest konieczne. 
Olbrzymią wszakże zasługą R. Laskowskiego jest to, że ustalenia W. Mańczaka powiązał on z opisem fleksyjnym wszystkich odmiennych części mowy. Nikt tego wcześniej nie zrobił. Można, oczywiście, założyć, że skoro to rzeczownik narzuca sąsiadującemu w zdaniu elementowi rodzaj gramatyczny, w opisie fleksyjnym wszystkich odmiennych części mowy powinien znajdować się taki sam zestaw nazw rodzajów, jaki posiada klasa rzeczowników. Użyty w konkretnym zdaniu rzeczownik posiadający jeden z sześciu rodzajów gramatycznych nakazywałby wybór form czasownika, przymiotnika i liczebnika w identycznym rodzaju. Tak w istocie dzieje się w zdaniu dwaj mili panowie przyszli. Rzeczownik pan, który ma rodzaj męskoosobowy, nakazuje liczebnikowi, przymiotnikowi i czasownikowi przyjęcie form tego właśnie rodzaju. W wielu jednak wypadkach sprawa akomodacji rodzajowej jest o wiele bardziej złożona.

Wspomnieliśmy wyżej o zasobie form rodzajowych czasownika. W liczbie pojedynczej ma on trzy różne formy rodzajowe (chodzit, chodziła, chodziło), a w liczbie mnogiej dwie (chodzili, chodziły). Można przyjąć, że w opisie fleksyjnym czasownika wydzielamy formy rodzajowe zgodnie z listą rodzajów rzeczownika. Wtedy jednak zasoby form rodzaju męskoosobowego, męskożywotnego i męskonieżywotnego byłyby w liczbie pojedynczej identyczne, a w liczbie mnogiej identyczne byłyby zasoby form rodzaju męskożywotnego, męskonieżywotnego, żeńskiego i nijakiego. Nie trzeba dodawać, że taki sposób opisu gramatycznego nie mógłby zostać uznany za ekonomiczny. Owa rozrzutność jeszcze bardziej by się uwidoczniła w zestawieniach form rodzajowych przymiotników i liczebników, gdzie form synkretycznych jest jeszcze więcej.

Roman Laskowski proponuje inne rozwiązanie problemu akomodacji rodzajowej. Jego spojrzenie można nazwać metagramatycznym. Na początku bowiem układa on paradygmaty czasowników, przymiotników i liczebników, biorąc pod uwagę kształt form rodzajowych. W następnym zaś etapie pokazuje, jak powinny czasowniki, przymiotniki i liczebniki reagować na konkretne wymaganie rodzajowe ze strony rzeczowników. Buduje w ten sposób szereg reguł pomostowych, dzięki którym z zasobu form czasowników, przymiotników i liczebników wybierane są te, które spełniają oczekiwanie użytego w zdaniu rzeczownika.

Syntetyczne przedstawienie reguł pomostowych zmieściło się w GWJP na dwóch stronach druku. Śmiem twierdzić, że jest to jedna z najbardziej czasochłonnych syntez, jakie kiedykolwiek powstały w naszym językoznawstwie. O ile bowiem w wypadku czasowników sprawa nie jest bardzo skomplikowana, o tyle w wypadku przymiotników i liczebników twórca reguł musiał prześledzić tysiące kontekstów diagnostycznych, by ostatecznie zweryfikować prawidłowość postulowanych reguł.

Jak już wspomniałem, sformułowanie reguł pomostowych między rzeczownikiem a czasownikiem jest dość proste i można je przedstawić za pomocą następujących zdań warunkowych: 
Jeżeli rzeczownik w liczbie pojedynczej wymaga od czasownika rodzaju męskoosobowego, męskożywotnego lub męskożywotnego, czasownik przybiera formę rodzaju męskiego.

$\checkmark$ Jeżeli rzeczownik w liczbie pojedynczej wymaga od czasownika rodzaju żeńskiego, czasownik przybiera formę rodzaju żeńskiego.

$\checkmark$ Jeżeli rzeczownik w liczbie pojedynczej wymaga od czasownika rodzaju nijakiego, czasownik przybiera formę rodzaju nijakiego.

$\checkmark$ Jeżeli rzeczownik w liczbie mnogiej wymaga od czasownika rodzaju męskoosobowego, czasownik przybiera formę rodzaju męskoosobowego.

$\checkmark$ Jeżeli rzeczownik w liczbie mnogiej wymaga od czasownika rodzaju męskoosobowego pejoratywnego, męskożywotnego, męskonieżywotnego, żeńskiego lub nijakiego, czasownik przybiera formę rodzaju niemęskoosobowego.

W regułach pomostowych pomiędzy rzeczownikiem a przymiotnikiem trzeba uwzględnić nie tylko liczbę, ale też przypadek. Nieformalnie, proces uzależnienia rodzaju przymiotnika od sąsiadującego z nim w zdaniu rzeczownika ująć można za pomocą następujących zdań warunkowych:

$\checkmark$ Jeżeli rzeczownik w liczbie pojedynczej i w mianowniku wymaga od przymiotnika rodzaju męskoosobowego, męskożywotnego lub męskonieżywotnego, przymiotnik przybiera formę rodzaju męskiego.

$\checkmark$ Jeżeli rzeczownik w liczbie pojedynczej i w mianowniku wymaga od przymiotnika rodzaju żeńskiego, przymiotnik przybiera formę rodzaju żeńskiego.

$\checkmark$ Jeżeli rzeczownik w liczbie pojedynczej i w mianowniku wymaga od przymiotnika rodzaju nijakiego, przymiotnik przybiera formę rodzaju nijakiego.

$\checkmark$ Jeżeli rzeczownik w liczbie pojedynczej i w bierniku wymaga od przymiotnika rodzaju męskoosobowego lub męskożywotnego, przymiotnik przybiera formę rodzaju męskożywotnego.

$\checkmark$ Jeżeli rzeczownik w liczbie pojedynczej i w bierniku wymaga od przymiotnika rodzaju męskonieżywotnego, przymiotnik przybiera formę rodzaju męskonieżywotnego.

$\checkmark$ Jeżeli rzeczownik w liczbie pojedynczej i w bierniku wymaga od przymiotnika rodzaju żeńskiego, przymiotnik przybiera formę rodzaju żeńskiego.

$\checkmark$ Jeżeli rzeczownik w liczbie pojedynczej i w bierniku wymaga od przymiotnika rodzaju nijakiego, przymiotnik przybiera formę rodzaju nijakiego.

$\checkmark$ Jeżeli rzeczownik w liczbie pojedynczej i w dopełniaczu, celowniku, narzędniku lub miejscowniku wymaga od przymiotnika rodzaju męskoosobowego, męskożywotnego, męskonieżywotnego lub nijakiego, przymiotnik przybiera formę rodzaju nieżeńskiego.

$\checkmark$ Jeżeli rzeczownik w liczbie pojedynczej i w dopełniaczu, celowniku, narzędniku lub miejscowniku wymaga od przymiotnika rodzaju żeńskiego, przymiotnik przybiera formę rodzaju żeńskiego. 
Jeżeli rzeczownik w liczbie mnogiej i w mianowniku wymaga od przymiotnika rodzaju męskoosobowego, przymiotnik przybiera formę rodzaju męskoosobowego.

$\checkmark$ Jeżeli rzeczownik w liczbie mnogiej i w mianowniku wymaga od przymiotnika rodzaju męskoosobowego pejoratywnego, męskożywotnego, męskonieżywotnego, żeńskiego lub nijakiego, przymiotnik przybiera formę rodzaju niemęskoosobowego.

$\checkmark$ Jeżeli rzeczownik w liczbie mnogiej i w bierniku wymaga od przymiotnika rodzaju męskoosobowego, przymiotnik przybiera formę rodzaju męskoosobowego.

$\checkmark$ Jeżeli rzeczownik w liczbie mnogiej i w bierniku wymaga od przymiotnika rodzaju męskożywotnego, męskonieżywotnego, żeńskiego lub nijakiego, przymiotnik przybiera formę rodzaju niemęskoosobowego.

W pozostałych przypadkach przymiotniki mają jedną tylko formę dla wszystkich rodzajów.

Sformułowanie reguł pomostowych między rzeczownikiem a liczebnikiem również wymagało prześledzenia wielu kontekstów diagnostycznych. Formalne reguły akomodacyjne zaproponowane przez R. Laskowskiego dla relacji z liczebnikami typu pięć można przedstawić za pomocą następujących zdań warunkowych:

$\checkmark$ Jeżeli rzeczownik w liczbie mnogiej i w mianowniku lub bierniku wymaga od liczebnika typu pięć rodzaju męskoosobowego, liczebnik przybiera formę rodzaju męskoosobowego.

$\checkmark$ Jeżeli rzeczownik w liczbie mnogiej i w mianowniku lub bierniku wymaga od liczebnika typu pięć rodzaju męskożywotnego, męskonieżywotnego, żeńskiego lub nijakiego, liczebnik przybiera formę rodzaju niemęskoosobowego.

W wypadku liczebników $d w a$, trzy i cztery autor reguł pomostowych nie opatruje ich form etykietą rodzajową, a jedynie uzależnia wybór konkretnej formy ( $d w a j$, dwóch, dwie, dwa, trzej, trzech, trzy, czterej, czterech, cztery) od rodzaju rzeczownika aktualnie sąsiadującego z liczebnikiem. Wydaje się, że zadanie można by znacznie ułatwić za pomocą dość racjonalnego odróżnienia liczebników dwa, trzy, cztery od liczebników dwóch, trzech, czterech. Pierwsze trzy liczebniki pojawiałyby się w zdaniach typu dwaj, trzej, czterej bracia, dwie, trzy, cztery siostry, dwa, trzy, cztery koty idą, natomiast druga trójka wchodziłaby wyłącznie w relacje z rzeczownikami w rodzaju męskoosobowym (dwóch, trzech, czterech panów idzie). Rozwiązanie to zaproponowałem w swoich opisach języka polskiego (por. Bobrowski 2005: 291). Dzięki niemu znika między innymi problem dwóch pozornie tylko alternatywnych mianowników, tj. dwaj i dwóch, który od wielu lat jest „przemycany” w kolejnych gramatykach języka polskiego.

Należy jednak raz jeszcze podkreślić, że zauważone przez Romana Laskowskiego i starannie opisane problemy akomodacji rodzajowej są kamieniem milowym na drodze do adekwatnego opisu gramatycznego polszczyzny. Dzięki jego syntetycznemu ujęciu za pomocą reguł pomostowych udało mi się stworzyć alternatywną koncepcję polskiego rodzaju gramatycznego, którą przedstawiłem po raz pierw- 
szy w 2006 r. (por. Bobrowski 2006a). Zakłada ona, że każdy rzeczownik wybiera w swoim opisie leksykalnym jedną z możliwych dróg wyznaczonych za pomocą następującej matrycy ogólnej:

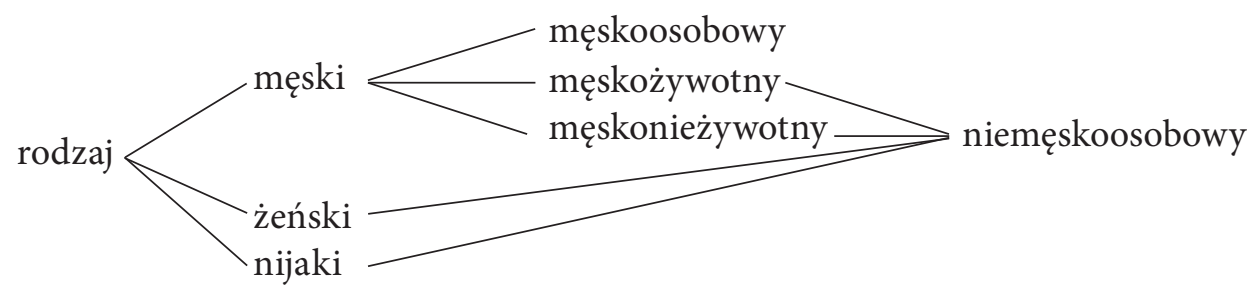

która może mieć także taką postać:

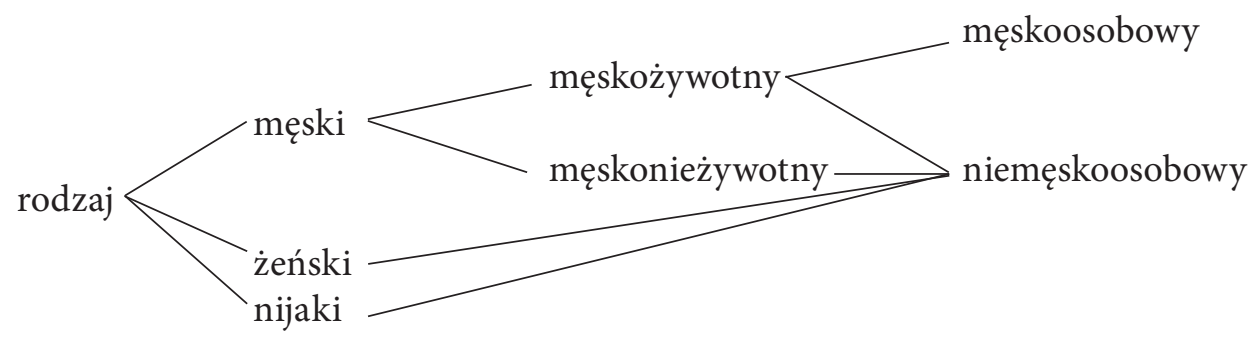

W opisie leksykalnym każdego rzeczownika wybierana byłaby więc jedna z pięciu ścieżek:

1a. Rodzaj $\rightarrow$ męski $\rightarrow$ męskoosobowy, np. pan, dyrektor (w wypadku przyjęcia pierwszej matrycy).

1b. Rodzaj $\rightarrow$ męski $\rightarrow$ męskożywotny $\rightarrow$ męskoosobowy, np. pan, dyrektor (w wypadku przyjęcia drugiej matrycy).

2. Rodzaj $\rightarrow$ męski $\rightarrow$ męskożywotny $\rightarrow$ niemęskoosobowy, np. kot, pies.

3. Rodzaj $\rightarrow$ męski $\rightarrow$ męskonieżywotny $\rightarrow$ niemęskoosobowy, np. stół, piec.

4. Rodzaj $\rightarrow$ żeński $\rightarrow$ niemęskoosobowy, np. szafa, pani, mysz.

5. Rodzaj $\rightarrow$ nijaki $\rightarrow$ niemęskoosobowy, np. dziecko, brzemię.

Nie wdając się w szczegóły, to znaczy pomijając na razie kwestię, czy rzeczowniki pan i kot powinny mieć wspólne dwa odcinki ścieżki czy tylko jeden, można powiedzieć, że rozwiązanie to samo w sobie zawiera pomosty między cechami rodzajowymi rzeczownika a cechami rodzajowymi czasownika, przymiotnika i liczebnika. Nadto ustala pewną, dość zresztą zrozumiałą hierarchię cech - szczególnie gdy idzie o cechy zawierające element męsk-. Intuicyjnie skłonni jesteśmy chyba uznać, że rodzaj męski jest kategorią nadrzędną w stosunku do rodzaju męskoosobowego, męskożywotnego i męskonieżywotnego. Propozycja ta jest przy tym w początkowym swym stadium identyczna $\mathrm{z}$ koncepcją rodzaju zawartą $\mathrm{w}$ gramatykach tradycyjnych, ale nie zakłada istnienia zależności pomiędzy rodzajem rzeczownika a jego 
liczbą. Sąd zatem, że w języku polskim są trzy rodzaje rzeczownika można - po przyjęciu pewnych założeń - uznać za prawdziwy.

Każdy bowiem rzeczownik wysyła do sąsiadujących leksemów polecenie rodzajowe, w którym ukazana jest pełna ścieżka jego „oczekiwań”. Zatem rzeczownik pan nakaże wybrać rodzaj męski, męskoosobowy (pierwsza matryca) lub rodzaj męski, męskożywotny, męskoosobowy (druga matryca). Wybór cechy rodzajowej będzie zależał od tego, jakim rodzajem dysponuje leksem akomodowany w określonej sytuacji. Jeżeli będzie to polecenie wysłane do czasownika iść w czasie przeszłym, a poleceniem towarzyszącym będzie nakaz przyjęcia liczby pojedynczej, to czasownik wybierze rodzaj męski (szedł), bo tylko ten rodzaj pasuje do jego opisu fleksyjnego. Jeśli natomiast rzeczownik narzuci równocześnie z poleceniem przyjęcia jednego $\mathrm{z}$ dwóch lub trzech rodzajów liczbę mnogą, to wówczas czasownik musi przyjąć rodzaj męskoosobowy, bo tylko ten pasuje do jego opisu fleksyjnego.

$\mathrm{Z}$ punktu widzenia relacji pomiędzy rzeczownikiem i akomodowanym przez niego przymiotnikiem wynika wszak, że z dwóch zaproponowanych wyżej matryc rodzajowych sensowniejsza wydaje się matryca druga, w której cecha męskożywotny jest nadrzędna w stosunku do cechy męskoosobowy. W wypadku bowiem połączenia rzeczownika pan z przymiotnikiem mity cecha rodzajowa, którą odbiera przymiotnik wraz z poleceniem przyjęcia liczby pojedynczej, to męskożywotny. $\mathrm{W}$ opisie fleksyjnym przymiotnika w liczbie pojedynczej nie ma osobnych form rodzaju męskoosobowego, są one natomiast w liczbie mnogiej.

Jeżeli z kolei rzeczownik stół nakaże przymiotnikowi $d u \dot{z} y$ wybrać rodzaj męski, męskonieżywotny, niemęskoosobowy, a jednocześnie narzuci mu liczbę pojedynczą i biernik, to wówczas przymiotnik musi przyjąć formę rodzaju męskonieżywotnego $d u \dot{z} y$, bo tylko ten z trzech rodzajów pasuje do fleksyjnego opisu przymiotnika w bierniku liczby pojedynczej. W opisie tym jest wprawdzie drugi biernik (dużego), ale ma on cechę rodzajową męskożywotny. W wypadku gdy rzeczownik stół nakaże przymiotnikowi przyjąć inny przypadek w liczbie pojedynczej, wówczas cechą rodzajową zgodną z opisem fleksyjnym przymiotnika będzie cecha męski, w wypadku zaś, gdy rzeczownik narzuci przymiotnikowi liczbę mnogą, to w dopełniaczu, celowniku, narzędniku i miejscowniku przymiotnik przyjmie jedyne możliwe formy

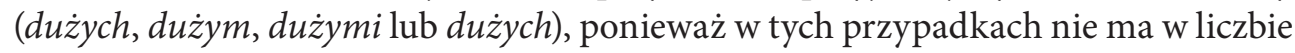
mnogiej zróżnicowania rodzajowego. Jeśli zaś rzeczownik stót nakaże przymiotnikowi przyjąć w liczbie mnogiej mianownik lub biernik, wtedy przymiotnik przyjmie cechę rodzajową niemęskoosobowy, bo tylko ta cecha $\mathrm{z}$ trzech zaproponowanych będzie pasowała do opisu przymiotnika.

Wydaje się zatem, że zaproponowana przeze mnie koncepcja opisu rodzaju gramatycznego w języku polskim jest nie tylko adekwatna na poziomie opisowym, ale też spełnia oczekiwania, które sformułowali Zygmunt Saloni i Marek Świdziński, kiedy pisali, że kwestią dyskusyjną jest tylko to, ,jaką liczbę rodzajów dla języka polskiego najwygodniej i najrozsądniej jest przyjąć" (por. Saloni, Świdziński 1985: 80). 
Jest i najwygodniejsza, i w miarę rozsądna. Nawiązuje wprawdzie do gramatyki tradycyjnej, ale należy wyraźnie powiedzieć - nikłe by były szanse na jej powstanie, gdyby nie było wcześniejszych analiz Witolda Mańczaka, Zygmunta Saloniego, a przede wszystkim Romana Laskowskiego.

\section{Literatura}

Bobrowski I., 2005, Składniowy model polszczyzny, Kraków.

Bobrowski I., 2006a, Jeszcze o rodzaju gramatycznym rzeczownika, „Polonica” XXVI-XXVII, s. 231-243.

Bовrowsкi I., 2006b, Pejoratywizacja, [w:] I. Bobrowski, K. Kowalik (red.), Od fonemu do tekstu. Prace dedykowane Profesorowi Romanowi Laskowskiemu, Kraków, s. 89-93.

BogusŁaWski A., 2009, On case, gender and related phenomena in Polish (for the umpteenth time), „Linguistica Copernicana” 1, s. 13-75.

GWJP: S. Urbańczyk (red.), Gramatyka wspótczesnego języka polskiego, t. 1.: Z. Topolińska (red.), Składnia, t. 2.: R. Grzegorczykowa, R. Laskowski, H. Wróbel (red.), Morfologia, Warszawa 1984.

KuCA£A M., 1978, Rodzaj gramatyczny w historii polszczyzny, Wrocław.

LAsKowsKi R., 1998, Kategorie morfologiczne języka polskiego - charakterystyka funkcjonal$n a$, [w:] R. Grzegorczykowa, R. Laskowski, H. Wróbel (red.), Gramatyka wspótczesnego języka polskiego. Morfologia, Warszawa, s. 151-224.

MaŃCZAK W., 1956, Ile jest rodzajów w języku polskim?, „Język Polski” XXXVI, s. 116-121. SALONI Z., 1976, Kategoria rodzaju we współczesnym języku polskim, [w:] R. Laskowski (red.), Kategorie gramatyczne grup imiennych w języku polskim, Materialy konferencji Pracowni Gramatyki Współczesnej Polszczyzny Instytutu Języka Polskiego PAN, Zawoja, 13-15 XII 1974, „Prace Instytutu Języka Polskiego PAN” nr 14, Wrocław, s. 43-78, 96-106.

SAlONi Z., ŚwidzińsKi M., 1985, Składnia współczesnego języka polskiego, Warszawa.

SzOBER S., 1953/1923, Gramatyka jezyka polskiego, Warszawa.

\section{Roman Laskowski's concept of grammatical gender in Polish Summary}

Probably the most elaborate intellectual construct in Roman Laskowski's morphology is his schematic presentation of the bridgeheads linking grammatical gender in Polish nouns to verbs, adjectives, and numerals. Although it occupies just two pages of print, to complete this study Laskowski had to analyze thousands of syntactic diagnostic contexts. The present paper tries to recall and comment on Laskowski's original concept of grammatical gender in Polish. 